\title{
Evolution of Online Social Networks: A Conceptual Framework
}

\author{
Junghun Kim ${ }^{1}$, Choonseong Leem ${ }^{1}$, Byungun $\mathrm{Kim}^{1} \&$ Youngjoon Cheon ${ }^{2}$ \\ ${ }^{1}$ Department of Information and Industrial Engineering, Yonsei University, Seoul, Korea \\ ${ }^{2}$ Creativity and Innovation Management Center, Yonsei University, Seoul, Korea. \\ Correspondence: Youngjoon Cheon, Creativity and Innovation Management Center, Yonsei University, \\ Shinchon-dong 134, Seoul,120-749, Korea. E-mail: taisama@naver.com
}

Received: May 6, 2012 Accepted: December 15, 2012 Online Published: March 28, 2013

doi:10.5539/ass.v9n4p208 URL: http://dx.doi.org/10.5539/ass.v9n4p208

\begin{abstract}
Booming industry recently Online Social Networks company's market success factors and coping strategies for change has focused attention from all walks of life. In particular, Facebook, Twitter and other social networking platform, a leading user experience companies' technological excellence and the main part of the discussion is related to excellence. However, most previous studies of the usefulness or user acceptance of sites, pattern, design excellence, such as the concept of local debate unfold around them. Therefore, the market dynamics of online social network field changes and the future evolution of corporate strategy and does not reflect the same aspects that synthetically has the limit. In this study proposes online social network's evolutionary path and changed factor from three perspectives of technology, suppliers, and users, and provides implications through examples of existing business cases.
\end{abstract}

Keywords: SNS, OSN, social network, social network evolution, social network transition

\section{Introduction}

Due to the widespread distribution of the smartphone, Online Social Networks (OSNs) have become a global phenomenon(Boyd \& Ellison, 2007). An OSN can be defined as a community website which connects people in relationship by sharing useful information, multimedia content, and more with friends or other users.

Recently, a number of OSNs have gained millions of users. In particular, Facebook has been growing increasingly popular among world-wide users since 2004. Other OSNs such as YouTube, Flickr, and LinkedIn facilitate the interaction for individuals and communities who share common interests and activities. According to Nielsen Online's latest research, social networking and blog sites are crucial for online activity. More than two-thirds of the global online population visit and participate in social networks and blogs(Pallis et al., 2011; Nielsen Online Report, 2009). This means that OSNs are likely to be a critical part of personal and commercial online interaction (O'reilly \& Battelle, 2009). As time goes by, more sites are launched or closed. Some sites maintain existing social networks, but others fail to retain their members. Researchers suggest that these phenomena are important when studying and forecasting of growth strategies of online business.

However, most perspectives focus on particular aspects, such as the use of the pattern and acceptance model, the marketing strategy, or network economics. Although these themes inform research by drawing from theoretical propositions, most studies are not sufficient to explain and forecast the holistic and complex interactions of players in the OSN industry.

The focus of our research is to describe continuance factors of large OSNs as providing a conceptual evolution framework. In this paper, we suggest an evolution framework for analyzing the intergenerational transition of OSNs. To accomplish this, we first examine the emerging OSN trend by looking at the launching rate data then give an analysis by reviewing related studies. We will then present the evolution framework and apply it to large-scale OSNs. Lastly, we conclude with a statement on the limitation of this study and suggestions for future study.

\section{Timeline of Online Social Networks}

To date, meaning of Online Social Networks was defined a variety of views. OSNs are hypermedia text designed as sharing system of photos and materials, commercial.

It is identified as 'virtual community' texts, and their content is opened by proactive users who request to acquire 
information and communicate between users (Jahnke, 2009). Although various interpretations would be reasonable for analyzing the context of OSN business, most researchers have reached a consensus about 'Link, participation and sharing' (Boyd \& Ellison, 2007; Jahnke, 2009).

Since introduced by SixDegrees.com, founded in 1997, the concept of 'OSN' has received more and more attention in business and culture. Some research has identified the original archetype of OSN to be Classmates.com or ICQ Buddy, which exhibit a significant communication model. In an extreme case, Peace/EcoNet, founded in 1987, is regarded as the 'Original Model of OSN' (Cachia et al., 2007). However, some analysts are discovering that the core component of OSN is the convergence between informal and formal relationship patterns. As noted above, 'SixDegrees.com' is seen to be the beginning point of OSNs(Boyd \& Ellison, 2007). But during 2000-2005, most OSNs have closed due to competition and market dynamics. Table 1 shows the rate of OSN launches by year (WIKIPEDIA, 2011).

Table 1. Rate of OSN launches by year

\begin{tabular}{|c|c|c|}
\hline Date & OSNs & Number \\
\hline 1995 & Classmates.com & 1 \\
\hline 1996 & Bolt.com & 1 \\
\hline 1997 & CaringBridge, AsianAvenue & 2 \\
\hline 1998 & Xanga, Care2, Open Diary, Fotki & 4 \\
\hline 1999 & $\begin{array}{l}\text { Cyworld, BlackPlanet, LiveJournal, Kiwibox,VampireFreaks.com, HR.com, } \\
\text { Advogato }\end{array}$ & 7 \\
\hline 2000 & $\begin{array}{l}\text { Habbo, Mixi, Friends Reunited, deviantART, Trombi.com, LunarStorm, } \\
\text { IRC-Galleria, Hospitality Club, Faceparty, dol2day, MouthShut.com, Playahead, } \\
\text { Playlist.com, WorldFriends }\end{array}$ & 14 \\
\hline 2001 & $\begin{array}{l}\text { StumbleUpon, My Opera, Partyflock, CozyCot, Athlinks, Frühstückstreff, } \\
\text { Decayenne, Meetup.com, OneWorldTV, Wasabi }\end{array}$ & 10 \\
\hline 2002 & $\begin{array}{l}\text { Friendster, MyLife, Last.fm, Skyrock, Fotolog, Plaxo, iWiW, Ryze, } \\
\text { Travellerspoint, FilmAffinity, Elftown, Hub Culture }\end{array}$ & 12 \\
\hline 2003 & $\begin{array}{l}\text { LinkedIn, Myspace, hi5, Netlog, MyHeritage, Gaia Online, WAYN, Multiply, } \\
\text { Delicious, XING, itsmy, CouchSurfing, Nexopia, DontStayIn, LifeKnot, } \\
\text { MEETin, OUTeverywhere, tribe.net }\end{array}$ & 18 \\
\hline 2004 & $\begin{array}{l}\text { Facebook, Windows Live Spaces, Tagged, Orkut, Viadeo, Hyves, Draugiem.lv, } \\
\text { Grono.net, Zoo.gr, aSmallWorld, Taringa!, Cloob, Faces.com, Yelp. }\end{array}$ & 14 \\
\hline 2005 & $\begin{array}{l}\text { Qzone, Bebo, douban, myYearbook, StudiVZ, Renren, Buzznet, MocoSpace, } \\
\text { Stickam, TravBuddy.com, Focus.com, Gather.com, Biip.no, LibraryThing, } \\
\text { Blogster, MOG, Ning }\end{array}$ & 17 \\
\hline 2006 & $\begin{array}{l}\text { Twitter, VKontakte, Badoo, Odnoklassniki, Nasza-klasa.pl, Tuenti, CafeMom, } \\
\text { ReverbNation.com, italki.com, GamerDNA, MyAnimeList, MyChurch, } \\
\text { Muxlim, aNobii, Crunchyroll, Eons.com, Goodreads, Jaiku, Listography, } \\
\text { Nettby, OneClimate, Shelfari, Vox, Wattpad, WebBiographies, Wer-kennt-wen }\end{array}$ & 26 \\
\hline 2007 & $\begin{array}{l}\text { Flixster, Flickr, Sonico.com, Geni.com, Livemocha, weRead, ibibo, Cellufun, } \\
\text { BigAdda, fubar, Ravelry, SocialVibe, Indaba Music, JammerDirect.com, } \\
\text { Wakoopa, Zooppa, WiserEarth, kaioo, NGO Post, Cake Financial, } \\
\text { DailyStrength, Disaboom, Epernicus, Experience Project, FledgeWing, } \\
\text { InterNations, LinkExpats, mobikade, Pingsta, Quechup, SciSpace.net, } \\
\text { TeachStreet, Tumblr, Virb }\end{array}$ & 34 \\
\hline 2008 & $\begin{array}{l}\text { Social Life, FetLife, Cross.tv, ResearchGate, Identi.ca, Academia.edu, MUBI, } \\
\text { Gays.com, Avatars United, GovLoop, Kaixin001, Lafango, MeettheBoss, Plurk, } \\
\text { Present.ly, Raptr, ScienceStage, TalentTrove, Talkbiznow, Taltopia, Xt3, } \\
\text { Yammer, Youmeo }\end{array}$ & 23 \\
\hline 2009 & $\begin{array}{l}\text { Foursquare, Hotlist, DailyBooth, Exploroo, gogoyoko, Qapacity, } \\
\text { ShareTheMusic, WeOurFamily }\end{array}$ & 8 \\
\hline 2010 & $\begin{array}{l}\text { WeeWorld, folkdirect, Goodwizz, Audimated.com, Federated Media's BigTent, } \\
\text { Blauk, FitFinder, Google Buzz, Passportstamp }\end{array}$ & 9 \\
\hline
\end{tabular}


At the start of the new millennium, online users drastically increased. Internet access become Electronic commerce began to be actively and online dating sites were spread worldwide. List up some features of online industry in early 2000. Talk Web 2.0 which represent middle of 2000. After middle of 2000, Smart phone has contributed to settle various cultures with explosive growth of OSNs.

In the above data, we observe three inflection points. (See Figure 1.) Each point is explained by a change or appearance of key technology such as web technology, mobile device, or network infrastructure.

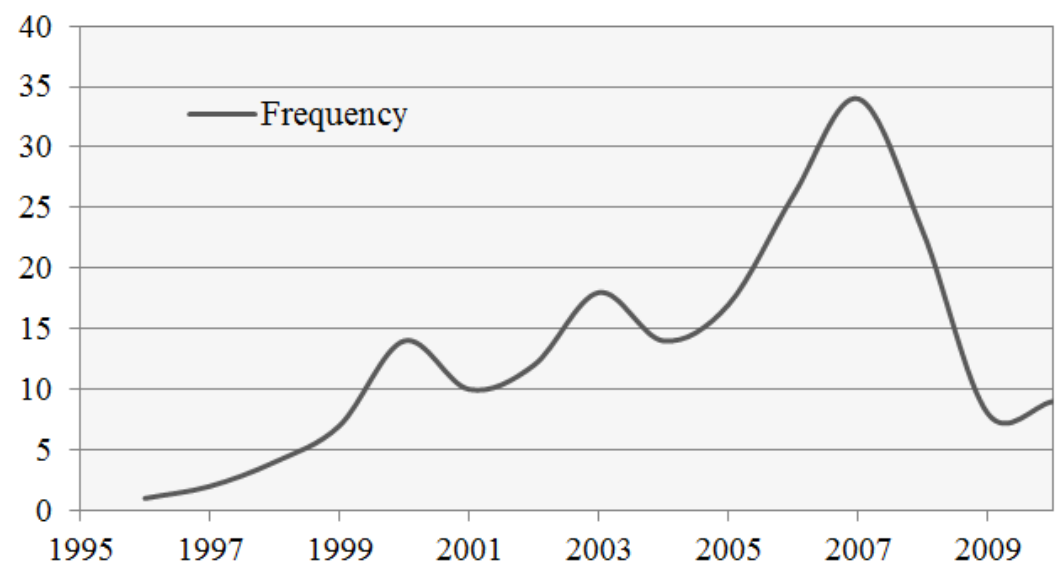

Figure 1. Emergence rate of OSNs

Due to the current wide spread of the Internet, expanding the network by being based, user-friendly environment than they were able to communicate with each other, resulting in online social networks (OSN) site can dramatically increase the number of subscribers. Management Information Systems and HCI researchers, including the social sciences this trend "the proliferation of social computing" was often defined as(Cachia et al 2007). OSNs spread of social computing time of the parent generation to the analysis of 200 cycles, such as Figure1 If you can see the changes. Generate the flow of time; depending on the number of OSNs changing phenomenon requires the analysis.

In this study, OSN's first created and then destroyed, and over time, another phenomenon that produces a variety of services, which is repeated, the following explanation for this phenomenon is to evaluate specifically on the topic.

1) Age OSNs are generated according to the flow of factors that affect

2) OSNs generated to maintain the sustainability of the evolutionary factors

\section{Motivation of Intergenerational Development Facilitated by Web 2.0 Society}

\subsection{Intergenerational Development Force of OSN Business}

Much research in the field of Technological Management/Management Information Systems has suggested that Evolution and Path dependent improvement is crucial in OSN business. Technological acceptance cycle and life cycle analysis are typical methods of analyzing the evolution in OSN business. This means either a qualitative or a quantitative approach is appropriate in researching this phenomenon(Jahnke, 2009; Keavney, 1995, Oxendine, 2003). 'Web 2.0', suggested by Tim O'Reilly, includes the timely evolution model(Blackshaw \& Nazzaro, 2004; O'reilly \& Battelle, 2009). In addition, other researchers explore the determining elements of lead or active users as one of the approaches for OSN development. User-centered blog designs and open source concepts have consistently expanded(Okazaki, 2005; Steinfield et al., 2008). Therefore, the system is likely to provide processing of user-centered demands, and establishing the foundation of on-demand search engines or platforms(Nambisan \& Baron, 2005; O'reilly \& Battelle, 2009).

The introduction of smart devices, stimulated by the development of the iPhone, was a catalyst for 'mobile service business'. This change is identified as 'Web 3.0' which consists of a matured and differentiated system(O'reilly, 2007; O'reilly \& Battelle, 2009; Tapscott, 2006). Developmental opportunities in mobile web and ubiquitous systems are classified as 'Smart 3.0', enforcing contingent cognition of environment and M-to-M or M-to-P interaction(Lassila \& Handler 2007; Martignoni \& Stranoevska-Slabeva, 2007; Tapscott, 2006; Tredinick, 2006). 
Through researching such services as augmented reality and social tagging, Martignoni has once suggested the possibility of Web 3.0 which overcomes the physical limitations(Martignoni, 2007). The guidance, feedback and knowledge related with such a pervasive system provide a vehicle for developing a user-specific interface(Bakhouya \& Gaber, 2006; Kourouthanasis et al., 2010). Add-on platforms and responsive systems have been integrated in network evolution and tendencies of functionality-based development of devices. In this context, Intergenerational Model Research based on analyzing critical cases in OSN business (Cachia et al., 2007; Cusumano \& Gawer, 2002).

With regard to the effects of OSN on a diverse society, socioeconomic research identifies the Platform concept based on the bilateral market business model, which was mainly studied by Industrial Organization and Strategic Management researchers (Baldwin, 2005; Gawer, 2009). Such representative players as Google and Android platform-providing networks - control the mechanism of interaction between OSN enterprises by enforcing the dominant logic of Network system (Baldwin et al., 2009; Eisenmann et al., 2006; Lerner et al., 2006).

\subsection{Technology, User and Supplier, and Industrial Components in OSN Business}

In addition to the intergenerational dimension of OSN business, we propose the component-based analysis of OSN business. For example, iPhone and iTunes have created a new market paradigm called 'App Market', representing transactions in the online environment. Firefox, an open source-based web browser, has had an impact on the change in stakeholders within the industry (Baldwin, 2005). Add-on software, provided by the main players in the industry, allows small businesses to access potential customers. Interface/agent-based analysis also support such as positive relations with various change. This is the technological context of the OSN evolution.

Building on this perspective, the user-oriented approach could also be the cornerstone of OSN business research(Cachia et al. 2007; Cusumano \& gawer, 2002; Kourouthanasis et al., 2010; Georgiu, 2007). The salience of information acceptance aspects of diversity effects is more likely to be emphasized and thus will be reflected more on the analysis of digital content sharing (music, photo and link-based information) and the service model of the open market. While resistance and competition between web sites, Facebook, Flicker, Myspaces are aligning the Users and enforcing the users to share the contents in various setting by connecting on OSN Sites (Cachia et al., 2007).

However, other findings also propose the service provider-oriented approach. This is effective for analyzing the context of OSN business. Previous studies have focused on the appeal of the open source business model for capturing the intuitive notion that within group rivaly and between group differ in the competition for contents market share (Gnyawali, Fan \& Penner, 2010). The crowdsourcing strategy has had an impact on the business in examining the possibility of exploiting the pool of user-based information (Tapscott, 2006; Tredinick, 2006). In this context, the boundary between industries has been expanded by the varied settings in OSN business players.

The literature provides relatively few indications of the nature of the comprehensive interaction between technology, the user, and the supplier. (See Table 2.) We propose the holistic framework for analyzing and forecasting the trend of the OSN industry by extending the previous argument. (See Figure 2.) It seems difficult to conclude that this framework is generalized in overall interpretations. However, by analyzing the strands of time change and structuring the pattern of OSN evolution, we can attempt to come to grips with this puzzling phenomenon which is reminiscent of previous studies. 
Table 2. Related perspectives

\begin{tabular}{|c|c|c|c|c|}
\hline \multirow{2}{*}{ Author } & \multirow{2}{*}{ Description } & \multicolumn{3}{|l|}{ Perspective } \\
\hline & & Technology & User & Supplier \\
\hline $\begin{array}{l}\text { Cusumano and } \\
\text { Gawer (2002) }\end{array}$ & $\begin{array}{l}\text { Diffusion of add-on software, modularity } \\
\text { and extension of existing business are } \\
\text { intensifying }\end{array}$ & $\checkmark$ & & $\checkmark$ \\
\hline Eisenman (2006) & $\begin{array}{l}\text { Sharing, openness and richness of the } \\
\text { scope in information economics by the } \\
\text { introduction of Online Social Network }\end{array}$ & $\checkmark$ & & $\checkmark$ \\
\hline Tapscott (2006) & $\begin{array}{l}\text { Searching for potential profit is more } \\
\text { important than cost leadership }\end{array}$ & $\checkmark$ & $\checkmark$ & \\
\hline $\begin{array}{l}\text { Armstrong and } \\
\text { Wright (2007) }\end{array}$ & $\begin{array}{l}\text { Homing cost and searching cost is } \\
\text { diversified and dispersed by the } \\
\text { introduction of multi-channel platform }\end{array}$ & & $\checkmark$ & $\checkmark$ \\
\hline Cachia et al (2007) & $\begin{array}{l}\text { Extendible virtual reality is intensified by } \\
\text { the introduction of ubiquitous technology }\end{array}$ & $\checkmark$ & $\checkmark$ & \\
\hline Georgiu (2007) & $\begin{array}{l}\text { Cognitive strategy is critical in the } \\
\text { contingent and ubiquitous perspective }\end{array}$ & $\checkmark$ & $\checkmark$ & \\
\hline $\begin{array}{l}\text { Baldwin and } \\
\text { Woodard (2009) }\end{array}$ & $\begin{array}{l}\text { Diversified industrial structure and } \\
\text { complex design of system }\end{array}$ & $\checkmark$ & & $\checkmark$ \\
\hline
\end{tabular}

\section{Evolution Framework of OSN}

This study seeks to focus on the fundamental concept of OSNs, their main developmental factors, and the evolutionary aspect according to the passage of time. Through this, we propose the following as analytical elements: Contents Connectivity, which represents the evolution of the interoperability of services used by OSNs(Armstrong \& Wright, 2007), Platform Access, which accounts for the change in service structures(Picard, 1989; Schultz \& Orlikowsky, 2004), Information Behavior, which represents the information search methods employed by OSN users(Chang et al., 2010), Social Intention, which represents the change in the methods of managing inter-user relationships(Nambisan \& Baron, 2005; Schultz \& Orlikowsky, 2004), Service Provision, which represents the evolution of the service infrastructure of businesses(Gawer, 2009), and Business Environment, which represents the change in the operational strategy of businesses(Jeon \& Lee, 2007).(See Table 3.) 


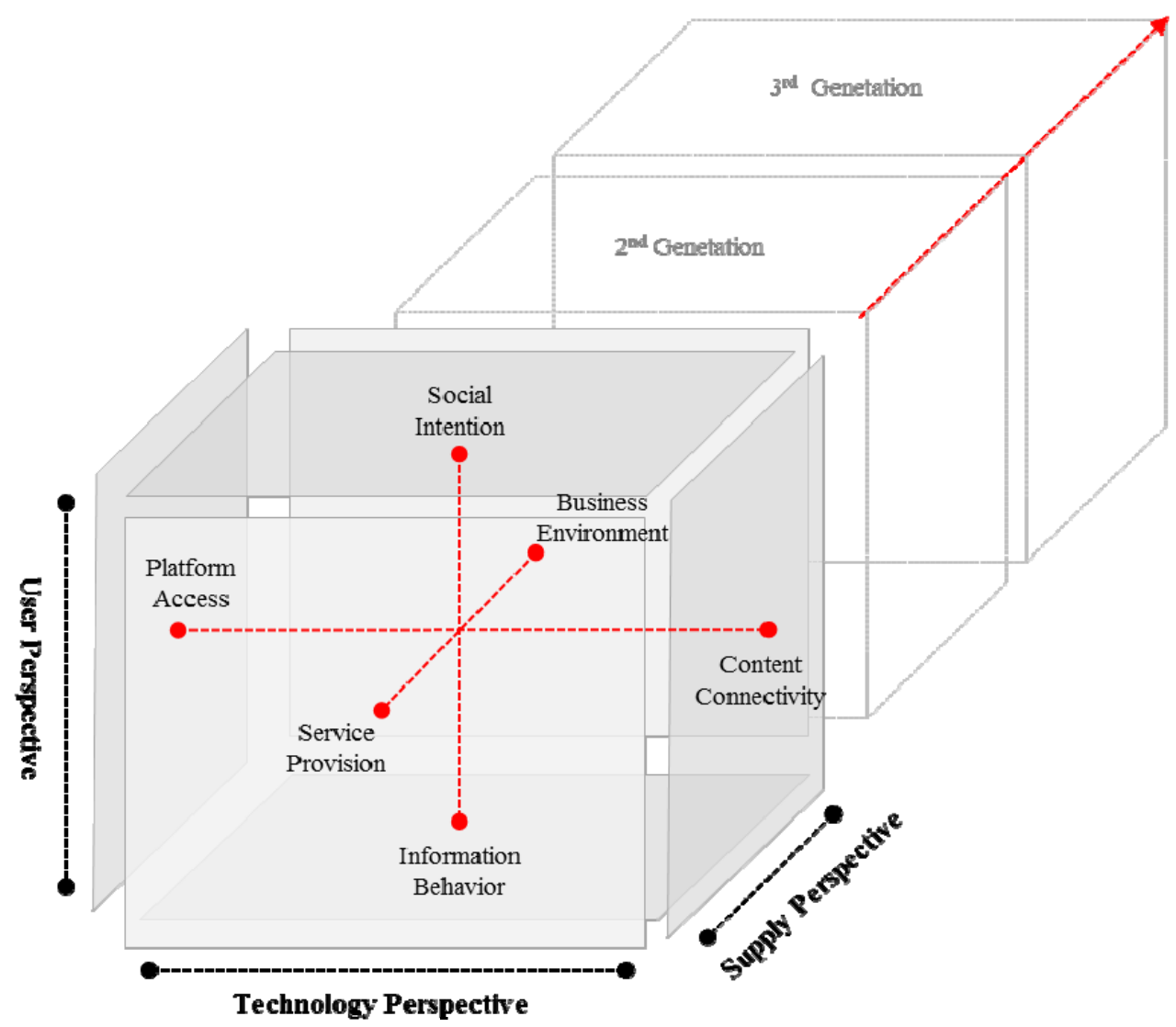

Figure 2. Evolution framework for OSN

Table 3. Scheme of evolution framework

\begin{tabular}{|c|c|c|}
\hline View & Attribution & Description \\
\hline \multirow{2}{*}{ Technology } & $\begin{array}{l}\text { Content } \\
\text { Connectivity }\end{array}$ & Change in service interoperability \\
\hline & $\begin{array}{l}\text { Platform } \\
\text { Access }\end{array}$ & $\begin{array}{l}\text { Technological Intermediaries for the connection between participant in the } \\
\text { On-line environment }\end{array}$ \\
\hline \multirow{2}{*}{ User } & $\begin{array}{l}\text { Information } \\
\text { Behavior }\end{array}$ & $\begin{array}{l}\text { Searching Strategy and Discovering potential resource for acquiring Brand Equity } \\
\text { by the dispersion of the Information }\end{array}$ \\
\hline & $\begin{array}{l}\text { Social } \\
\text { Intention }\end{array}$ & $\begin{array}{l}\text { Extended relationship overcome formal communication pattern in traditional } \\
\text { system and society }\end{array}$ \\
\hline \multirow{2}{*}{ Supplier } & $\begin{array}{l}\text { Service } \\
\text { Provision }\end{array}$ & Change of Infrastructure facilitating the exploitation of Online Social Network \\
\hline & $\begin{array}{l}\text { Business } \\
\text { Environment }\end{array}$ & Change in business operational strategies \\
\hline
\end{tabular}

\section{Evolutionary Path and Framework of Online Social Network Business}

In this study, we shall distinguish the 1st and 2nd generation centered on Web 2.0, which brought about generation-making changes in the early OSN services. Also, the point from which OSNs became smart device-based shall be defined as the 3rd generation (O'reilly, 2007; O'reilly \& Battelle, 2009; Tapscott, 2006). (See Table 4.)

The studies by McKinney et al (2002) and Tarasewich et al (2002) are standard in viewing service interoperability from the technological perspective. Previously, service methods were limited to suppliers 
mechanically entering information, which the consumer then either purchased or accepted. Yet, with the increase in communication and free connectivity through mobile devices, an open system emerged on account of changes in the supplier-user relationship, and in peer-to-peer sharing. Along a similar line, Boyd \& Ellison (2007) suggests that, with the arrival of the ubiquitous environment in which the electronic and the physical spaces come together, ever-connected mobile services are dominant. Eisenman et al (2006) also emphasizes that the supplier-user interaction has become easier with various combinations of different methods such as keywords, tags, and source codes. In terms of the changes in the service structure, conventional Industrial Organization researchers - Picard, Kats, and Shapiro - have proposed an economic model through platform evolution brought on by the network effect and compatibility (Katz \& Shaprio, 1994; Picard, 1989).

From the user perspective, O'Reilly's study, which shows that the way users relate to each other has been evolving since the emergence of Web 2.0, is standard (Tapscott, 2006). Whereas fragmented relationships, which amounted to simple information trading, constituted the principal relationship in the Web 1.0 era, network-based interaction becomes dominant in Web 2.0 and after. Information system researchers claim that, if OSNs are limited to establishing friendship between users with similar interests or people who know each other, requirements have recently been proposed for the vitalization of online communities and the expansion of their influence and lifestreams (Ebling et al., 2002; Hays \& Hill, 2006). They also see a change in that communities centered on core users understand and accept the social embeddedness of individual constituents. Hays \& Hill and Gibson have noted that users have become more diverse in their desire for expression, and Cachia et al (2007) has stated that, with the evolution of the web, the pattern of information acquisition by users has evolved from the initial searching and browsing to publishing and subscribing. Furthermore, there are studies that propose comprehensive marketing strategies capitalizing on the nature of SNS, the crowd funding pattern, and behavior duplication of users (Chang et al., 2010; McKinney et al., 2002; Tarasewich et al., 2002).

From the service provider perspective, Cachia et al (2007)'s study can be interpreted in terms of changes in the level of service provision. He suggests that, whereas the web changed from PC-centric to user-centric in the 2nd generation, it has now become data-centric based on the semantic-web in the 3rd generation. Jeon and Lee (2007) have noted that OSN service providers moved on from a competitive relationship in the initial "walled garden" environment to a coalition relationship in an open business environment.

Table 4. Result of OSN evolution

\begin{tabular}{lllll}
\hline \multirow{2}{*}{ View } & \multirow{2}{*}{ Attribution } & Generation & \\
\cline { 3 - 5 } & & 1st & 2nd & 3rd \\
\hline Technology & Content & People to & People to People, Machine to & Pervasive and \\
& Connectivity & Machine & Machine & Contextual \\
& Platform Access & Closed & Open & Compatible \\
\multirow{2}{*}{ User } & Information & Search and & Publish and Subscribe & Acquiring and \\
& Behavior & Browse & & Reproduction \\
& Social Intention & Friendship & Lifestream & Social Embeddedness \\
& & Transactional & Relationships & \\
\multirow{4}{*}{ Supplier } & Service Provision & Provider-Centric & User-Centric & Data-Centric \\
& Business & Competition & Coalition & Convergence \\
& Environment & & & \\
\hline
\end{tabular}

\section{Case Study}

As mentioned earlier, each generational feature of the OSN (Online Social Network) service from the 'Evolution Framework' was checked against three (technology, user, supplier) major aspects. In each generation, OSN services come and go. At each point of such creation and extinction, various OSN evolution case scenarios can be observed. First, after the OSN service emerged in the first generation, it was extinguished in the second generation. Second, after the OSN service emerged in the first generation, although it was kept in the second generation, it was extinguished in the third generation. Third, after the OSN service emerged in the second generation, it was extinguished in the third generation. Fourth, after the OSN service emerged in the second generation, it was kept in the third generation. Finally, the OSN service emerged in third generation. (See Figure 3.) Through these case studies, note the cause of the emergence and extinction of OSN in the evolution scenario. 
1) Case 1: Success in 1st Generation, but failure in 2nd Generation

2) Case 2: Success in 1 st Generation and 2nd Generation, but failure in 3rd Generation

3) Case 3: Success in 2nd Generation, but failure in 3rd Generation

4) Case 4: Success in 2nd Generation and 3rd Generation

5) Case 5: Success in 3rd Generation

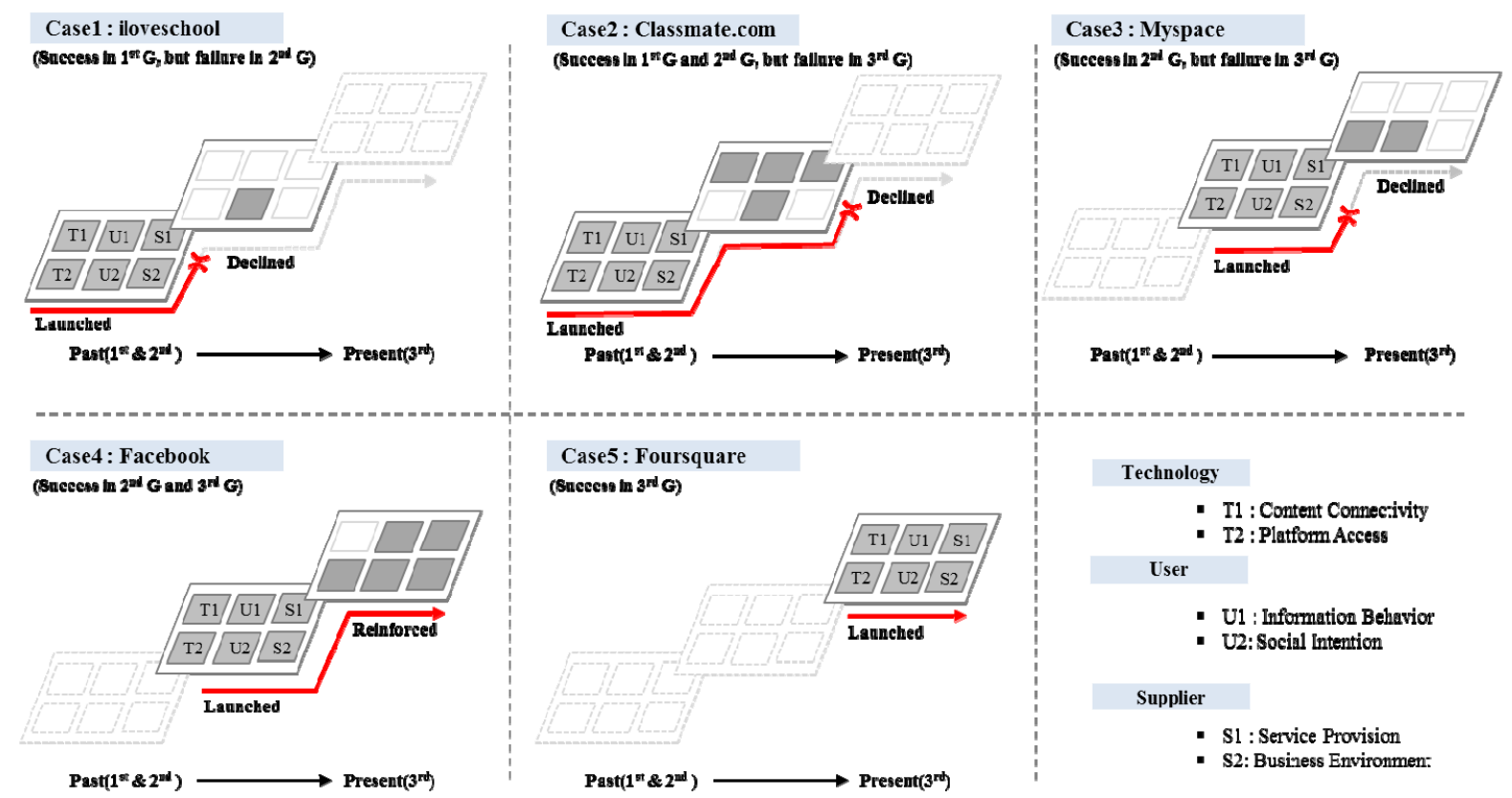

Figure 3. Evolution path about case study

\subsection{Iloveschool: 1st G (Success) to 2nd G (Failure)}

The iloveschool service was launched in late 1999. The service concept of iloveschool is reunion of people. It was designed to facilitate the finding of friends and acquaintances from elementary school, middle school, high school, and college by searching by school, name, and age on a web page of a personal computer. Based on these services in September 2000, iloveschool ranked \#8 in the world on alexa.com and had at least 10 million members in February 2002. It was the most famous of its time in Korea.

People's nostalgia of their past was the foundation for iloveschool's success as a 1st generation OSN service. However, insisting on the previous service methods with only minor changes without adapting to the new trend of reinforcing inter-user relationship through daily activities and the change in user node configuration led to its downfall in the 2nd generation. (See Table 5.)

Table 5. Evolution factor about iloveschool service

\begin{tabular}{|c|c|c|c|}
\hline View & Attribution & 1st Generation & 2nd Generation \\
\hline \multicolumn{2}{|c|}{$\begin{array}{l}\text { Technology Content } \\
\text { Connectivity }\end{array}$} & $\begin{array}{l}\text { Connect friends from same school } \\
\text { through alumni board }\end{array}$ & - \\
\hline & Platform Access & Single web-based service & - \\
\hline \multirow[t]{2}{*}{ User } & $\begin{array}{l}\text { Information } \\
\text { Behavior }\end{array}$ & $\begin{array}{l}\text { Search friends by school, name, and } \\
\text { age }\end{array}$ & - \\
\hline & Social Intention & $\begin{array}{l}\text { Vitalize alumni gatherings based on } \\
\text { graduation history }\end{array}$ & $\begin{array}{l}\text { Facilitate teacher gatherings and share } \\
\text { educational contents }\end{array}$ \\
\hline \multirow[t]{2}{*}{ Supplier } & Service Provision & PC-based web page & - \\
\hline & $\begin{array}{l}\text { Business } \\
\text { Environment }\end{array}$ & $\begin{array}{l}\text { Exclusive service through alumni } \\
\text { board }\end{array}$ & - \\
\hline
\end{tabular}




\subsection{Classmates.com: 1 st G (Success) to 2 nd $G$ (Semi-Success) to $3 \mathrm{rd}$ G (Failure)}

Classmates.com was an alumni community service that started in 1995. Through online school boards, users from the same school could share activities, and friends from the same school could search and connect with each other. It can be considered the first OSN service in the U.S., which once surpassed 40 million members and competed neck-and-neck with Facebook and Myspace.

Users' interest in a community of alumni brought a fervent response in the 1st generation OSN service. When shifting to the 2nd generation OSN service, by introducing various functions and new concepts such as finding friends' friends and showing employment information of the alumni, meeting user needs could be actively sustained. However, when transitioning to the late 2nd generation and the 3rd generation, service declined considerably because Classmates.com did not connect to other services via 'open API' and mobile devices.(See Table 6.)

Table 6. Evolution factor about classmate.com service

\begin{tabular}{|c|c|c|c|c|}
\hline View & Attribution & 1st Generation & 2nd Generation & 3rd Generation \\
\hline \multirow[t]{2}{*}{ Technology } & $\begin{array}{l}\text { Content } \\
\text { Connectivity }\end{array}$ & $\begin{array}{l}\text { Connect friends from same } \\
\text { school through alumni board }\end{array}$ & $\begin{array}{l}\text { Add friends and contents } \\
\text { together }\end{array}$ & - \\
\hline & Platform Access & Single web-based service & - & - \\
\hline \multirow[t]{2}{*}{ User } & $\begin{array}{l}\text { Information } \\
\text { Behavior }\end{array}$ & $\begin{array}{l}\text { Search friends by school name, } \\
\text { and age }\end{array}$ & $\begin{array}{l}\text { Relationship-based search } \\
\text { through friend's friend }\end{array}$ & - \\
\hline & Social Intention & $\begin{array}{l}\text { Vitalize alumni gatherings based } \\
\text { on graduation history }\end{array}$ & $\begin{array}{l}\text { Employment info shared } \\
\text { using alumni relations }\end{array}$ & - \\
\hline \multirow[t]{2}{*}{ Supplier } & $\begin{array}{l}\text { Service } \\
\text { Provision }\end{array}$ & PC-based web page & $\begin{array}{l}\text { Increase accessibility with } \\
\text { widgets }\end{array}$ & - \\
\hline & $\begin{array}{l}\text { Business } \\
\text { Environment }\end{array}$ & $\begin{array}{l}\text { Exclusive service based on } \\
\text { alumni items }\end{array}$ & - & - \\
\hline
\end{tabular}

\subsection{Myspace: 2 nd G (Success) to 3rd G (Failure)}

Myspace service provided a link between indie musicians and fans since its launch in mid-2003. Its service was very well-received by users and it reached over 100 million members in October 2006 and 76 million user visits per month. Based on these statistics, Myspace topped the ranking of OSN services for a short time.

In spite of leading the OSN industry by connecting music and artists, Myspace fell behind in the competition in the 3rd generation due to critical problems such as usability decline, an impractical plan of profit, and having too many banners on the page. (See Table 7.)

Table 7. Evolution factor about Myspace service

\begin{tabular}{llll}
\hline View & Attribution & 2nd Generation & 3rd Generation \\
\hline Technology & $\begin{array}{l}\text { Content } \\
\text { Connectivity }\end{array}$ & $\begin{array}{l}\text { Real-time user-to-user communication } \\
\text { using music and artists }\end{array}$ & - \\
& Platform Access & Open API for various functions & $\begin{array}{l}\text { API granting access from various } \\
\text { devices }\end{array}$ \\
User & $\begin{array}{l}\text { Information } \\
\text { Behavior }\end{array}$ & $\begin{array}{l}\text { Generate information actively using music } \\
\text { / artists }\end{array}$ & - \\
& Social Intention & Solidarity with friends through music & $\begin{array}{l}\text { Mobile-based real-time music } \\
\text { playback and conversation }\end{array}$ \\
Supplier & $\begin{array}{l}\text { Service } \\
\text { Provision }\end{array}$ & Increase accessibility with widgets & - \\
& $\begin{array}{l}\text { Business } \\
\text { Environment }\end{array}$ & $\begin{array}{l}\text { Service cooperation centered on } \\
\text { individual users }\end{array}$ & - \\
\hline
\end{tabular}




\subsection{Facebook: 2nd G (Success) to 3rd G (Success)}

In 2004, Facebook began with the alumni community at Harvard University. Since then, its service scope was extended to the alumni communities of the U.S. and Canada and service was made available to the public in 2006. Based on an open platform service, Facebook ranked \#10 in the world on alexa.com and it surpassed 7 billion members in 2011.

In the initial phase, the growth of the Facebook service was a slow process as with other basic OSN services. After it launched its open platform service in May 2007, an influx of services from third parties and their convergence created a synergy effect. Success of the service in the 2nd generation encouraged the service's positive extension. When shifting to the 3rd generation, accessibility and portability of mobile devices provided new services such as enhanced real-time communication and collective intelligence contents. These features of Facebook led to the 3rd generation of OSN service. (See Table 8.)

Table 8. Evolution factor about facebook service

\begin{tabular}{|c|c|c|c|}
\hline View & Attribution & 2nd Generation & 3rd Generation \\
\hline \multirow[t]{2}{*}{ Technology } & $\begin{array}{l}\text { Content } \\
\text { Connectivity }\end{array}$ & $\begin{array}{l}\text { Real-time communication between } \\
\text { individual users and company }\end{array}$ & - \\
\hline & Platform Access & Open API for various functions & API granting access from various devices \\
\hline \multirow[t]{2}{*}{ User } & $\begin{array}{l}\text { Information } \\
\text { Behavior }\end{array}$ & $\begin{array}{l}\text { Spread data actively using search / } \\
\text { address book }\end{array}$ & $\begin{array}{l}\text { Content recommendation using collective } \\
\text { intelligence }\end{array}$ \\
\hline & Social Intention & $\begin{array}{l}\text { Relationship-building with friends using } \\
\text { Walls }\end{array}$ & $\begin{array}{l}\text { Real-time communication using mobile } \\
\text { notification }\end{array}$ \\
\hline \multirow[t]{2}{*}{ Supplier } & $\begin{array}{l}\text { Service } \\
\text { Provision }\end{array}$ & Increased accessibility with widgets & $\begin{array}{l}\text { Recommendation technology based on } \\
\text { accumulated data }\end{array}$ \\
\hline & $\begin{array}{l}\text { Business } \\
\text { Environment }\end{array}$ & $\begin{array}{l}\text { Attract variety of services through } \\
\text { open service }\end{array}$ & $\begin{array}{l}\text { Re-configure services by accepting } \\
\text { services from other environments }\end{array}$ \\
\hline
\end{tabular}

\subsection{Foursquare: $3 r d$ G (Success)}

Foursquare was launched in 2009 and has reached 10 million members based on its mobile positioning service. This service grew rapidly under the alliance of users and businesses. Also, its corporate value was assessed at $\$ 1$ billion.

Drawing on the portability of mobile devices, this service supported a type of service using location information such as store location, store information, and user reviews. Based on the service concept, it stood out in the 3rd generation OSN service by receiving a 10-million-dollar investment and cooperating with 10 thousand companies including Starbucks and the press. (See Table 9.)

Table 9. Evolution factor about foursquare service

\begin{tabular}{|c|c|c|}
\hline View & Attribution & 3rd Generation \\
\hline \multirow[t]{2}{*}{ Technology } & Content Connectivity & New, location-based communication methods for stores and users \\
\hline & Platform Access & Location information technology by sharing location API \\
\hline \multirow[t]{2}{*}{ User } & Information Behavior & Location-based web search using mobile devices \\
\hline & Social Intention & Search information on visited locations and share with friends in real-time \\
\hline \multirow[t]{2}{*}{ Supplier } & Service Provision & Collect AP data and provide precise location with GPS \\
\hline & Business Environment & $\begin{array}{l}\text { New service inter-operation through partnerships with businesses that } \\
\text { desire location-based promotion }\end{array}$ \\
\hline
\end{tabular}

\section{Conclusions}

This study has attempted to identify factors which play a role in the sustainability or extinction of OSNs. First, 
by organizing the top 200 OSNs by the year in which they were created, we have identified those that have continued, and failed, to grow. Second, we have examined the characteristics that distinguish different generations by analyzing the developmental trend of the web. Third, we have identified the core elements by analyzing the components and evolutionary trends of the OSN industry, and, based on these, we have deduced the conceptual evolutionary framework of OSNs, verifying it through case studies by examining the evolutionary scenario of each OSN.

Unlike previous studies, most of whose discussions centered on a localized concept of conventional OSN sites, this study was able to deduce the following points based on the evolutionary framework of OSNs. First, this study can provide a guide for service analysis from a comprehensive perspective by mapping the generational trend and industry components based on the passage of time. Second, business owners can diagnose the current state of their OSN service by applying this study so as to improve the service and sustain the site. Finally, we believe that this study will be highly applicable for planners when they initially design an OSN service, as it can be used to select the parameters by which the basic considerations of the service can be provided and verified.

While the OSN evolutionary framework as proposed by this study can provide a foundation for analysis, assessment, and planning, it is not without limitations. First, the main axis of this framework - the distinction between generations, and the core elements of the industry components - was deduced from the concept of web evolution (Web 1.0, 2.0, and 3.0), which has been an important concept on the web, and by studying various literature. However, additional considerations may be needed depending on the analytical perspective. Second, in the generational distinction of the framework - which can be defined variously as Web 3.0, Mobile Web 2.0, or Smart Web 3.0, depending on the researcher - the 3rd generation is still on-going, unlike the 1st and the 2nd generation,, which have come to a close. Thus, the core elements of the 3rd generation are open to possible changes.

To overcome such limitations, further study is needed to bolster the reliability of each element and component of the framework axis by reflecting the opinions of a variety of experts. Also, to further supplement this study, the functions of individual OSNs that represent the generational elements need to be mapped and quantitatively analyzed so as to provide precise numerical values.

Numerous OSN services are still coming onto, and going off, the scene. One may be able to quickly create a service at the first flash of a brilliant idea, but the reality is that it is difficult to turn it into a sustainable service. In such an uncertain reality, the OSN framework from an evolutionary perspective as proposed by this study can help determine the direction which the service will take. We believe that this study will play an important role in providing the foundation of future studies.

\section{References}

Armstrong, M., \& Wright, J. (2007). Two Sided Market, Competitive Bottlenecks and Exclusive Contracts. Economic Theory, 32(2), 353-380. http://dx.doi.org/10.1007/s00199-006-0114-6

Bakhouya, M., \& Gaber, J. (2006). Ubiquitous and Pervasive Application Design, Encyclopedia of Mobile Computing and Commerce, edited by Taniar, D, IGI Global, Melbourn, Austraila.

Baldwin, C. Y., \& Clark, K. B. (2005). The Architecture of Participation: Does code architecture mitigate free riding in the open source development model? Management Science, 52(7), 1116-1127. http://dx.doi.org/10.1287/mnsc.1060.0546

Blackshaw, P., \& Nazzaro, M. (2004). Consumer-Generated Media (CGM) 101: Word of Mouth is the Ace of the web-fortified consumer, Intelliseek White Paper. Retrieved from http://www.intelliseek.com/whitepaper

Boyd, D., \& Ellison, N. (2007). Social Network Sites: Definition, History and Scholarship. Journal of Computer Mediated Communications, 13(1), 210-230. http://dx.doi.org/10.1111/j.1083-6101.2007.00393.x

Cachia, R., Compano, R., \& Da Costa, O. (2007). Grasping the potential of Online Social Network. Technological Forecasting and Social Change, 74(8), 1179-1203. http://dx.doi.org/10.1016/j.techfore.2007.05.006

Chang, K. C., Chen, M. C., Hsu, C. L., \& Kuo, N. T. (2010). The effect of service convenience on post-purchasing behaviours. Industrial Management and Data Systems, 110(9). http://dx.doi.org/10.1108/02635571011087464

Cusumano, M., \& Gawer, A. (2002). The elements of Platform Leadership. Sloan Management Review, 43(3).

Ebling, M., John, B. E., \& Satyanarayanan, M. (2002). The Importance of Translucence in Mobile Computing Systems. ACM Transactions in Computer-Human Interaction, 9(1), 42-67. 
http://dx.doi.org/10.1145/505151.505153

Eisenmann, T., Parker, G., \& Alstyne, M. W. (2006). Strategies for Two-sided Markets', Harvard Business Review, Octobor. Harvard University Press, Cambridge, MS: USA.

Gawer, A. (2009). Platforms, Markets and Innovation. Edward Elgar Publishing Ltd, London, UK.

Georgiu, M. (2007). E-Commerce has a positive impact on Economic Growth. Social Science Research Network, Online Published.

Gnyawali, D. R., Fan, W., \& Penner, J. (2010). Competitive action and Dynamics in the Digital Age: An empirical investigation of social networking firms. Information Systems Research, 21(3), 594-613. http://dx.doi.org/10.1287/isre.1100.0294

Hays, J. M., \& Hill, A. V. (2006). Service guarantee strength: the key to service quality. Journal of Operations Management, 24(6), 753-764. http://dx.doi.org/10.1016/j.jom.2005.08.003

Jahnke, I. (2009). Dynamics of Social Roles in a Knowledge management community. Computers in Behavior, $26,833-846$.

Jeon, J. H., \& Lee, S. Y. (2007). Toward a mobile rich web application: mobile AJAX and Mobile Web 2.0. Proceedings of W3C Mobile AJAX Workshop.

Kakihara, M., \& Sørensen, C. (2001). Expanding the Mobility Concept. SIGGROUP Bulletin, 22(3), 33-37.

Katz, M. L., \& Shaprio, C. (1994). System Competition and Network Effects. The Journal of Economic Perspective, 8(2), 93-115. http://dx.doi.org/10.1257/jep.8.2.93

Keavney, S. M. (1995). Customer Switching Behavior in Service industries: an Explorative Study. Journal of Marketing, 59(2), 71-82. http://dx.doi.org/10.2307/1252074

Kourouthanasis, P. E., Giaglis, G. M., \& Karaiskos. (2010). Delineating Pervasiveness in pervasive information systems: a taxonomical framework and design implications. Journal of Information Technology, 25, 273-287. http://dx.doi.org/10.1057/jit.2009.6

Lassila, O., \& Handler, J. (2007). Embracing Web 3.0. IEEE Internet Computing, 11(3), 90-93. http://dx.doi.org/10.1109/MIC.2007.52

Lerner, J., Parag, A. P., \& Tirole, J. (2006). The Dynamics of Open Source Contributors. American Economic Review, 96(2), 114-118. http://dx.doi.org/10.1257/000282806777211874

Martignoni, R., \& Stranoevska-Slabeva, K. (2007). Mobile Web 2.0, 20th Bled e-Conference eMergence: Merging and emerging technologies, processes and institutions, June 4-6, 2007: Bled, Slovenia.

McKinney, V., Yoon, K., \& Zahedi, F. (2002). The measurement of web-customer satisfaction: An expectation and disconfirmation approach. Information Systems Research, 13(3), 296-315. http://dx.doi.org/10.1287/isre.13.3.296.76

Nambisan, S., \& Baron, R. (2005). Interactions in Visual customer environments: implications for product support and customer relationship management. Journal of Interactive Marketing, 21(2), 42-62. http://dx.doi.org/10.1002/dir.20077

Newson. A., Houthon, D., \& Patten, J. (2009). Bloging and other Social Media: exploiting the Technology and protecting the enterprise. Farnham, Englad: Gower.

Nielsen Online Report. (2009). Social networks \& blogs now 4th most popular online activity, ahead of personal email. Nielsen Reports. Retrieved from http://www.nielsen.com/us/en/insights/press-room/2009/social_networks_.html

O'reilly, T. (2007). What is web 2.0: Design Patterns and Business Models for the Next Generation of Software. Communications and Strategies, 1(17).

O'reilly, T., \& Battelle, J. (2009). Web Squared: Web 2.0 Five years on. Special Report of Web 2.0 Summit, O'REILLY.

Okazaki, S. (2005). New Perspective on M-Commerce Research. Journal of Electronic Commerce Research, $6(3), 160-164$.

Oxendine, A., Borgida, E., Sullivan, J. L., \& Jackson, M. S. (2003). The Importance of Trust and Community in developing and maintaining a community electronic network. International Journal of Human-Computer Studies, 58(6), 671-696. http://dx.doi.org/10.1016/S1071-5819(03)00037-5 
Pallis, D., Zeinalipour, M., \& Dikaiakos. D. (2011). Online Social Networks: Status and Trends, book chapter in the book Web Data Management Trails. Editors L. Jain and A. Vakali, Springer.

Picard, R. G. (1989). Media Economics: Concepts and Issues. Thousand Oaks, Calif: Sage Publications.

Safko, L., \& Brake, D. (2009). The Social Media Bible-Tactics, Tools and Business Success. John Wiley \& Sons, NJ. Hoboken.

Schultz, U., \& Orlikowsky, W. (2004). A Practice Perspective on Technology Mediated Relations. Information Systems Research, 15(1), 87-106. http://dx.doi.org/10.1287/isre.1030.0016

Steinfield, C., Ellison, N., \& Lampe, C. (2008). Social Capital, Self-esteem, and use of online network sites: A Longitudinal Analysis. Journal of Applied Developmental Psychology, 29, 434-445. http://dx.doi.org/10.1016/j.appdev.2008.07.002

Tapscott, D. (2006). Winning with Enterprise 2.0. New Paradigm Learning Corperation.

Tarasewich, P., Nickerson, R. C., \& Warkentin, M. (2002). Issues in Mobile E-commerce. Communications of the Association for Information Systems, 8, 41-64.

Tredinick, L. (2006). Web 2.0 and Business A pointer to the intranet of the future? Business Information Review, 23(4), 228-234. http://dx.doi.org/10.1177/0266382106072239

WIKIPEDIA. (2011). Retrieved from http://http://en.wikipedia.org/wiki/List_of_social_networking_websites 